\title{
Erratum to: Stratigraphy and tectonics of a time-transgressive ophiolite obduction onto the eastern margin of the Pelagonian platform from Late Bathonian until Valanginian time, exemplified in northern Evvoia, Greece
}

\author{
Rudolph Scherreiks • Guillermo Meléndez • \\ Marcelle BouDagher-Fadel · Georgia Fermeli • \\ Dan Bosence
}

Published online: 14 December 2014

(C) Springer-Verlag Berlin Heidelberg 2014

\section{Erratum to: Int J Earth Sci (Geol Rundsch) (2014) \\ 103:2191-2216 \\ DOI 10.1007/s00531-014-1036-3}

Unfortunately, the part of the details in the abstract had been erroneously omitted in the original publication. The correct abstract is given below:

\begin{abstract}
The obduction of an ophiolite sheet onto the eastern Pelagonian carbonate-platform-complex of the Hellenides began during the late Bathonian and ended with the
\end{abstract}

The online version of the original article can be found under doi:10.1007/s00531-014-1036-3.

R. Scherreiks $(\bowtie)$

Bayerische Staatssammlung für Geologie, Luisenstr. 37, 80333 Munich, Germany

e-mail: r.scherreiks@hotlinemail.com

G. Meléndez

Departamento de Geologia (Paleontologia), Universidad de Zaragoza, 50009 Saragossa, Spain

e-mail: gmelende@unizar.es

M. BouDagher-Fadel

Earth Sciences, University College London, Gower Street, London WC1E 6BT, UK

e-mail:m.fadel@ucl.ac.uk

G. Fermeli

Department of Historical Geology and Paleontology, University of Athens, Panepistimioupolis, Zographou, 15784 Athens, Greece e-mail: gfermeli@geol.uoa.gr

\section{Bosence}

Department of Earth Sciences, Royal Holloway University

of London, Egham TW20 0EX, UK

e-mail: d.bosence@es.rhul.ac.uk final emplacement of the ophiolite during Valanginian time. The early stages of obduction caused sub-aerial exposure of the platform, recorded by an unconformity of Callovian age, which is marked by laterites overlying folded and faulted, karstic substrates. The laterites have distinct ophiolitic geochemical-signatures, indicating that emergent ophiolite had been undergoing lateritic weathering. This unconformity coincides with widespread western-Tethyan, Callovian gaps, indicating that the obduction in the Hellenides was probably related to far-reaching plate-tectonic processes. Resumed gravitational pull and rollback of the subducted, oceanic leading edge of the Pelagonian plate presumably initiated the early Oxfordian transgression of shallow marine carbonates and the inundation of the temporarily exposed ophiolite. Platform drowning continued into Tithonian-Valanginian time, documented initially by reefal carbonates and then by below-CCD, carbonate-free radiolarian cherts and shales. Subsequently, siliciclastic turbidites, which apparently originated from uplifted Variscan basement, were deposited together with and over the radiolarite as the ophiolite nappe-sheet advanced. The nappe substrate underwent tectonic deformations of varying intensity while, polymictic mélange and syn-tectonic sedimentary debris accreted beneath the ophiolite and at the nappe-front. The provenience of the ophiolite-nappecomplexes of northern Evvoia most probably has to be looked for in the Vardar ocean. 